\title{
10. 政府衛星データプラットフォーム「Tellus（テルース）」について
}

\section{Japan's Open \& Free Satellite Data Platform "Tellus"}

\author{
田村 幸平* \\ Kohei TAMURA
}

\begin{abstract}
Tellus" is Japan's open and free satellite data platform, aimed at creating new business market utilizing satellite data. Despite the growing quantity and quality of earth observation satellite data across the world, there is plenty of room for industrial utilization. This paper introduces one of the Government of Japan's activities to promote the usage of satellite data, the Tellus data platform.
\end{abstract}

\section{1.はじめに}

現在，宇宙産業は技術革新や新規参入企業の増加等 を背景に，宇宙由来の様々なデー夕の質・量が抜本的 に向上しつつある。地球観測衛星デー夕 (以後, 特段 の言及が無い限り「衛星デー夕」という）についても, 単なる宇宙由来のデータではなく，ビッグデータの一 部として様々なデー夕と組み合わせ, $\mathrm{AI}$ 等の解析技術 を活用することで，多様な分野の課題に対しソリュー ションを提供していくことが期待されている。

他方，日本の衛星デー夕は，産業利用は限定的な状 況である。

この背景にある宇宙産業の現状や課題，それを解決 するべく経済産業省で開発を進めている政府衛星デー タプラットフォーム「Tellus (テルース)」について紹 介する。

\section{2 . 宇宙産業の現状と課題}

近年は超小型衛星の高性能化により衛星利用が低コ スト・低リスク化してきたことに加え，計算能力の進 歩により膨大なデー夕処理に対する技術的なハードル が下がっている。そのため, 海外だけでなく日本でも 宇宙分野への民間・ベンチャー企業の参入が進んでい る。しかし，日本の宇宙産業を見ると，全体の市場規 模が約1.2兆円と言われている中 ${ }^{1}$ その基盤となる宇 宙機器産業は官需によって支えられている。そこで, 経済産業省としては，利活用の広がりが期待される宇 宙利用産業を育て，これにより官需依存の強い宇宙機

*経済産業省製造産業局宇宙産業室

「写真測量とリモートセンシング」VOL. 59，NO. 1， 2020
器産業の民需ベースでのニーズも増やし, 民間事業者 の参入を增やす形での宇宙産業全体の拡大を狙うこと としている。

諸外国の状況を見ると，例えば米国では，政府機関 であるNOAA（米国海洋大気庁）が提供しているデー 夕は, Amazon や Google 等の IT 事業者のクラウド 環境のプラットフォームを通じて利用することも可能 となっている。そのプラットフォームの開発・維持を 行う IT 事業者は, プラットフォーム上で利用できる アプリケーションの開発を他のアプリケーション開発 事業者に募っており，こうした座組でプラットフォー ムの価值を高めている。また，欧州や豪州等において も，政府機関が関与する形で衛星データプラット フォームが整備されている。国によってデー夕提供の モデルは異なるものの, 政府が整備する衛星のデータ を原則としてオープン\&フリーな形で無償公開する仕 組みが整っている状況である。

翻って, 現在, 日本では, 地球規模での環境を捉え る環境衛星デー夕を中心に, 研究機関向けにはデー夕 のオープン\&フリー化がなされているものの, ビジネ スニーズが期待される地球観測衛星デー夕の産業利用 は限定的である。その理由としては，(1)ユーザからの リクエストベースで有償によりデータの標準処理及び 提供がなされていること, (2)デー夕量が膨大で一般 ユーザのコンピュータでは扱いづらいこと, (3)データ 解析にあたり高価なソフトウェアが必要であること等 により，衛星デー夕利用が進んでいないと言える。

1 宇宙産業ビジョン2030(平成29年 5 月29日, 宇宙政策委 員会決定） 


\section{3. 政府衛星データプラットフォーム Tellus}

こうした衛星デー夕利用への言わば「参入障壁」を 取り除き, 衛星デー夕利用促進を図るため, 経済産業 省は, 平成 30 年度に, クラウド環境でオープン \&フリー で衛星デー夕を利用することができる，政府衛星デー タプラットフォーム「Tellus」の開発に着手した2。 Tellus はアジャイル開発で進めており，平成31年 2 月 にプロトタイプ版をリリースするに至った ${ }^{3}$ (図 1)。

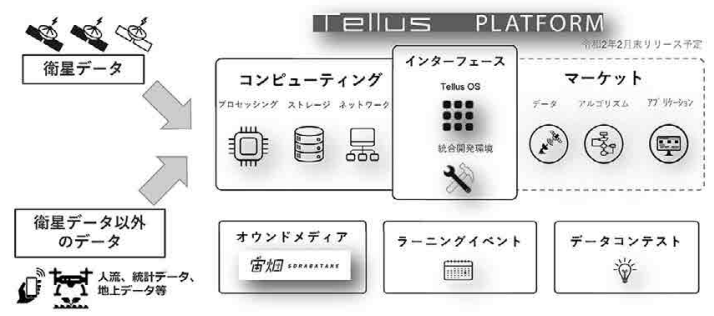

図 1 Tellus の構成イメージ

\subsection{Tellus のユーザ構成}

令和 2 年 1 月時点で, Tellusの登録ユーザは約 13,000 人であり,そのうち, 約 300 名が統合開発環境(後 述）の利用者数である。個人・法人, 宇宙産業/他産業 問わず，国内外の幅広いユーザが登録されている。

\subsection{Tellus の機能}

Tellus は，簡単なユーザ登録を行うことで利用でき る。その主な機能として, (1) Tellus OS と (2)統合開発 環境がある。

(1) Tellus OS では, 衛星データや地上デー夕を直感 的な操作で地図上に画像を重ねて表示することができ る。時系列や地域など様及な観点で比較することでイ ベント前後の差分やデー夕間の特性や傾向を読み取る ことが可能になる(図 2 参照)。

(2)統合開発環境では, Tellusに搭載されているデー 夕を使った解析やアプリケーション開発が可能であ る。統合開発環境にアクセスするだけで JupyterLab を介して Pythonや R といったプログラミング言語 を利用し，衛星データの画像処理や，デー夕同士の演 算処理等の解析を行うことができる。統合開発環境で は，Tellus 上の各種データと Jupyter Labが API で

2 平成30年度政府衛星データのオープンアンドフリー 化・データ利用環境整備事業（経済産業省）

3 https://www.tellusxdp.com/ja/

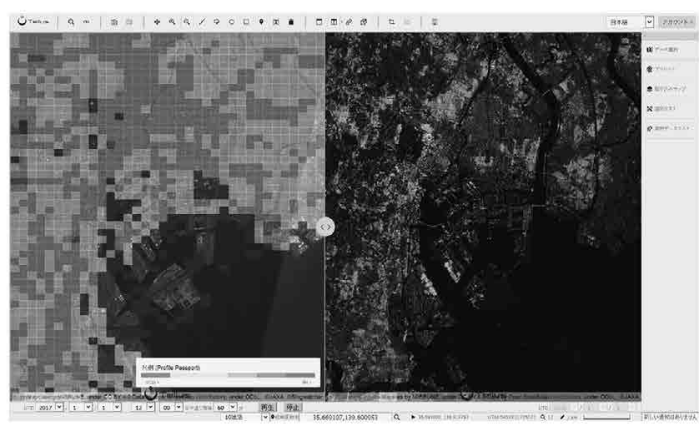

図 2 Tellus OS の画面サンプル

連携している。この統合開発環境の中で利用可能なク ラウド環境として「CPU：4 Core, メモリ：8 GB, ディスク：SSD 100GB」の性能を提供し, その他, 専 有環境や GPU サーバを現在無料で提供している。

上記機能を用いて Tellus 上で利用可能なデータと しては, 国立研究開発法人宇宙航空研究開発機構 （JAXA）や民間事業者等が運用する地球観測衛星の データがある。令和 2 年 1 月時点では, ASNARO- $1^{4}$, ASNARO- ${ }^{5}$ やつばめ (SLATS) ${ }^{6}$ 等が Tellusにおい てしか無料で閲覧できない衛星データとして特徵的で ある。

また, 衛星データ以外のデータとして, アメダスの 降水量や風向風速等の情報, スマートフォンの位置情 報を利用した人流情報, 地域経済分析システム (RESAS) 7といった衛星データ以外のデータを搭載し ている(図 3 参照)。衛星デー夕と組み合わせることで 新たなインサイトが得られることを期待している。

こうしたTellus の機能やデー夕を用いて新たな サービス,ソリューションが生まれることを期待して いる。例えば, Tellus を利用した海釣りスポット検索 アプリの開発を例にとると, (1)統合開発環境において, 衛星データとして GCOM-C の海面水温を可視化す る。(2)人流デー夕から, 混雑なく漁場へ行きやすい場 所を割り出す。(3)ひわりの雲画像やアメダスの風力 データから, 晴れていても風が稳やかそうな場所を推 測する。(4)これらの解析結果を重ね合わせ, 最適な釣 クスポットを導き出す, という一連の流れを Tellus 上 でアプリとして提供することが可能である。

4 (怢)パスコが運用する光学衛星

5 日本電気(侏が運用する合成開ロレーダ衛星

6 JAXAの超低高度衛星技術試験機「つばめ」

7 https://resas.go.jp/1 


\begin{tabular}{|c|c|c|}
\hline \multirow[t]{4}{*}{$\begin{array}{l}\text { 衛 星 } \\
\text { デー夕 }\end{array}$} & 光学 & $\begin{array}{l}\text { ALOS, SLATS, ASNARO- } 1 \text {, } \\
\text { Landsat- } 8\end{array}$ \\
\hline & $\begin{array}{l}\text { 合成開口 } \\
\text { レーダ }\end{array}$ & ALOS- 2, ASNARO- 2 \\
\hline & 気象系 & $\begin{array}{l}\text { GCOM-C, ひまわり } 8 \text { 号, GSMaP, } \\
\text { MODIS }\end{array}$ \\
\hline & 標高 & ASTER GDEM 3, AW3D30 \\
\hline $\begin{array}{l}\text { 衛 星 } \\
\text { デー夕 } \\
\text { 以外 }\end{array}$ & \multicolumn{2}{|c|}{$\begin{array}{l}\text { アメダス1 分值, Profile Passport }{ }^{8}, \text { モバイル } \\
\text { 空間統計 }{ }^{9}, \text { RESAS }\end{array}$} \\
\hline
\end{tabular}

図 3 Tellusで利用可能な主なデータ（令和 2 年 1 月時点）

\section{4. 衛星デー夕利用促進の取組}

\section{1 衛星デー夕解析人材の育成}

衛星デー夕利用促進のためには, Tellusによる利用 環境の整備に加え, 実際に衛星デー夕を利用した解析 を行うデー夕解析人材の育成も重要である。そのため の取組として, (1)ハンズオン講座，(2) e ラーニング, (3)データコンテストを実施している。以下，それぞれ の概要を記す。

(1) ハンズオン講座（Tellus Satellite Boot Camp）

Tellus を使って衛星デー夕の解析を行うために，基 本的な使い方から実践的な解析手法までを学ぶことが できる無料のハンズオン講座 ${ }^{10}$ 。動画教材による $\mathrm{e}$ ラーニングでの事前学習を行った上で，2 日間の講座 を通じて, 衛星デー夕解析と機械学習を利用してデー 夕解析人材を育成し, 衛星デー夕を利用したビジネス の創出を図ることを目的としている。衛星デー夕の基 本的知識から, Tellus上での Python を使った衛星 デー夕画像解析演習, 機械学習に打ける物体検出概論 といった内容の講義・演習を受講することができる。

令和元年度は, 東京と大阪で 1 回ずつ開催した。

(2) e ラーニング (Tellus Trainer, TechAcademy $\times$

Tellus 初心者向け Tellus 学習コース)

上記 Tellus Satellite Boot Camp はハンズオン形式 での受講であるため, 開催場所・回数, 指導講師の数 等の制限があり，必ずしも希望者全員が参加できる訳 ではない。実際, 今年度開催した東京でのハンズオン

8 (㧣)゙ログウォッチャー提供

9 (㧣ドコモ・インサイトマーケティング提供

10 さくらインターネット(株), (侏) SIGNATE, 一般財団法 人リモート・センシング技術センターが運営
講座では，定員50名に対し，応募者は約290名であり， 大阪会場も同様に定員超過であった。そこで，様々な 事情によりハンズオン講座を受講できないユーザ層を ターゲットに, 令和元年度から, e ラーニング教材の提 供を開始した。

e ラーニングは無料で提供しており，2 種類ある。一

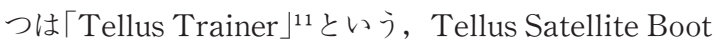
Camp と同じ内容のプログラムを受講できるもの。そ のため，プログラミング言語の経験がある者を対象と している。これに加え，プログラミング初心者向けの e ラーニング教材として,「TechAcademy $\times$ Tellus 初 心者向け Tellus 学習コース」を提供している ${ }^{12}$ 。 Python を用いて, 簡単な画像処理や衛星画像の加工, 数值予測の方法等をオンライン上で学ぶことができ る。これにより, 中学生以上の学生を含む若年層の Tellus ユーザの開拓も期待される。

\begin{tabular}{|c|c|c|c|}
\hline & $\begin{array}{c}\text { Tellus Satellite } \\
\text { Bootcamp }\end{array}$ & Tellus Trainer & $\begin{array}{c}\text { TechAcademy } \times \\
\text { Tellus }\end{array}$ \\
\hline 形式 & フークシコップ形式 & E-Learning形式 & E-L earning形式 \\
\hline 対象 & \multicolumn{2}{|c|}{ プロクラランクスキルを有するIT技術者 } & 初心者 \\
\hline 時期 & $\begin{array}{l}\text { 10月26,27日@東京 } \\
\text { 11月16,17日@大阪 }\end{array}$ & 11月21日 & 12月26日 \\
\hline $\begin{array}{c}\text { 講座内 } \\
\text { 容 }\end{array}$ & \multicolumn{2}{|c|}{ 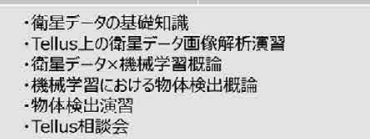 } & 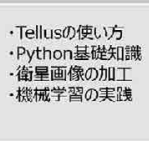 \\
\hline
\end{tabular}

図 4

施)

(3) データコンテスト (Tellus Satellite Challenge)

ある課題・テーマを設定し, 衛星デー夕と機械学習 を組み合わせたアルゴリズムを開発し，その精度の高 さを競うデータコンテスト。衛星データの利活用事例 を可視化し, 優秀なデータサイエンティストの発掘, 衛星デー夕の周知・啓蒙等を行うことでTellus の利活 用促進を目的とする。これまで,「合成開ロレーダ画像 を用いた土砂崩れ検知」(第 1 回), 「高分解能光学衛星 デー夕を用いた水域における船舶検出」(第 2 回), 「合 成開ロレーダデータを用いた海水領域の検知」（第 3 回）をテーマに開催し，「衛星データ×機械学習」の有 用性を検証している ${ }^{13}$ 。ある実際の業務上の課題(例： これまで作業員による衛星画像の目視判読を行ってい

11 https://tellustrainer2019.peatix.com/view

12 https://techacademy.jp/lp-tellus

13 株 SIGNATEのデータコンペティションを利用。 
るが判読に時間がかかっている等）に対し，衛星デー 夕と機械学習の組み合わせによって解決が期待される ようなものをテーマに設定している。こうしたデータ コンテストでのアルゴリズムの開発や精度の競争の結 果を, 課題保有者に活用してもらうことを睨んで実施 している。

\subsection{Tellus のオウンドメディア}

Tellus のオウンドメディアとして, 宇宙ビジネス情 報サイト「宙畑（そらばたけ）」を公開している14。宙 畑では, Tellus の使用方法や活用例の記事や, 衛星 データを中心とした幅広い宇宙産業にかかる国内外の ニュースを配信しており，宇宙分野への一般の関心を 惹きつける役割に加之, 実践的な Tellus の活用方法ま で学べるようになっている。

\section{3 光の他}

経済産業省の Tellus の事業とは別で, 民間主体での Tellus の開発への貢献と利用促進を目的として組成 した, Tellusを中心とした新ななエコノミ一創出を目 指すパートナーシップである xData Alliance（クロス データアライアンス) ${ }^{15}$ の活動もある。ビジネス開発, 人材育成，インフラ，投資，防災・セキュリティ，デー 夕収集, デー夕利活用といった多様な分野での貢献を 目指す民間事業者等 27 団体が加入しており（令和 2 年 1 月時点), アライアンス内での情報共有等を行ってい る。

\section{Tellus の課題及び今後の取組}

Tellus は衛星デー夕利活用を促進するための一つ の施策に過ぎない。まずは衛星デー夕に気軽に触れら れる環境を整備し, これまで衛星デー夕に触れてこな
かった人等が, Tellusを活用して既存業務の効率化や 新たなソリューション作りを行うきっかけを与えるも のとなることを期待している。そのためには Tellus の データプラットフォームとしての魅力を高めていくこ とが必要である。Tellus はアジャイル開発で進めてお り, Tellusを活用したユースケースを創出していくた めにも，ユーザの御意見を考慮しながら順次搭載デー 夕の量や機能, 使いやすさ等の充実化・改善を行って い。

今後の取組としては, 現在, Tellus 上では Tellus OS 及び統合開発環境という機能が備わっているのみであ るが，新たな機能として，「Tellus マーケット」を令和 2 年 2 月末に設ける予定である。Tellus マーケットを 通じて, Tellusに標準搭載されていない衛星デー夕, 衛星データ以外のデータ, 解析ツール, アルゴリズム 等がそれぞれのデータプロバイダから販売され，それ らを用いて Tellus 上で閲覧・解析等を行うことが可能 となる。これにより, 例えば, 現状の Tellus では提供 されていないデータが欲しいユーザは, Tellus マー ケットにて衛星デー夕を購入することもできるように なる。逆に，各種データやツールを保有・提供してい る者は,プロバイダとして Tellus を通じてそれを販売 することができる。Tellus の登録ユーザには宇宙産業 問わず様々な分野のユーザがいるため，これまでにな い分野のユーザを取り込むチャンスになりうると期待 している。

\section{参考文献}

平成 29 年度政府衛星データのオープン\&フリー化及び 利用環境整備に関する検討会報告書（2017年10月， 経済産業省) 